EUROPA REGIONUM TOM XXVIII ROK 2016

DOI: $10.18276 /$ er.2016.28-13

ANNA MAZUREK-KUSIAK

Uniwersytet Przyrodniczy w Lublinie

\title{
Ocena jakości zagospodarowania Centralnego Szlaku Rowerowego Roztocza
}

\section{Wprowadzenie}

$\mathrm{T}$ urystyka rowerowa w Polsce rozwija się bardzo dynamicznie. Aktywny wypoczynek na rowerze jest coraz bardziej popularny w polskim społeczeństwie oraz doskonale wpisuje się w fillozofię zdrowego stylu życia (Buczyńska 2013). Turystyka rowerowa włącza się także w nurt turystyki transgranicznej (Hajduk 2007, s. 87), dzięki której następuje rozwój regionów peryferyjnych, promocja lokalnych produktów turystycznych, integracja życia gospodarczego, kulturowego, technicznego i społecznego dwóch sąsiadujących ze sobą narodów (Sawicki 2010, s. 237-240). Jednakże niezbędnym elementem tej integracji jest budowa szlaków turystycznych. To szlaki w dużej mierze decydują o rozwoju funkcji turystycznych regionu oraz mogą stać się wiodącym produktem turystycznym danego obszaru (Stasiak 2012, s. 45-53). Szlak można zdefiniować jako ,pasmo przystosowane do ruchu krajoznawczo-wędrownego, pieszego, wodnego, rowerowego, konnego, prowadzone po oznakowanych trasach, przechodzące przez tereny krajobrazowo atrakcyjne i łączące obiekty lub ich zespoły, interesujące z przyrodniczego, kulturowego i technicznego punktu widzenia" (Krawczyńska 2012, s.1). Natomiast szlakiem rowerowym jest spójny ciąg rozwiązań technicznych, łączący miasta, miasteczka i wsie ze sobą obejmujący drogi dla rowerów, pasy rowerów oraz ulice o mniejszym natężeniu ruchu samochodowego wykorzystującą istniejącą infrastrukturę turystyczną, komunikacyjną i techniczną (Zarząd Główny PTTK 2007, s. 5). Szlak taki powinien prowadzić 
i ukazywać atrakcje regionu. Budowa szlaków w dużej mierze decyduje o rozwoju turystyki rowerowej regionu (Styperek 2002, s.25). Według GUS w Polsce jest ok. 13 tys. km szlaków rowerowych, jednak większość z nich nie spełnia standardów europejskich, zmuszają rowerzystów do schodzenia $\mathrm{z}$ rowerów z powodu zbyt dużego nachylenia powierzchni lub złej nawierzchni drogi (Kopta 2010, s. 10-15), dlatego chcąc rozwijać turystykę regionu powinno się zadbać o dobrą jakość dróg, prawidłowe oznakowanie szlaku, zabezpieczenie miejsc postojowych, noclegowych i gastronomicznych, tablic informacyjnych.

\section{Cel pracy i metody badawcze}

Celem artykułu było ocenienie jakości zagospodarowania infrastruktury turystycznej i rowerowej na transgranicznym Centralnym Szlaku Rowerowym Roztocza oraz wskazanie największych atrakcji na każdym z trzech odcinków szlaku.

Badania przeprowadzono metodą sondażu diagnostycznego, korzystając z techniki ankiety bezpośredniej i wywiadu telefonicznego. Autorską ankietę przeprowadzono wśród 175 rowerzystów mających powyżej 18 lat, przejeżdżających na omawianej trasie co najmniej $50 \mathrm{~km}$. Wywiad telefoniczny przeprowadzono z pracownikami urzędów gmin i miejsc noclegowych znajdujących się na trasie Centralnego Szlaku Rowerowego Roztocza po stronie Polskiej i dotyczył gównie ilościowej bazy noclegowej przystosowanej dla rowerzystów. Badania przeprowadzono w okresie od maja do września 2015 r. Materiał uzupełniono analizą danych statystycznych, analizą dokumentów urzędowych oraz studiami literatury przedmiotu.

\section{Charakterystyka obszaru badań}

Centralny Szlak Rowerowy Roztocza odznacza się średnim stopniem trudności. Podzielony jest na 3 etapy.

Pierwszy etap Centralnego Szlaku Rowerowego Roztocza biegnie od Kraśnika do Zwierzyńca, a jego długość wynosi $101 \mathrm{~km}$. Trasa prowadzi przez następujące miejscowości: Kraśnik - Stróża - Słodków Trzeci-Szastarka - Brzozówka - Stare Moczydła - Błażek - Batorz - Zdziłowice - Otrocz - Chanów - Łada - Goraj Kondraty -Hosznia Ordynacka - Gilów - Podlesie Duże - Radecznica - Dzielce Szczebrzeszyn - Topólcza-Zwierzyniec (www.szlakirowerowe.lubelskie.pl). Szlak ten prowadzi przez najciekawsze tereny Roztocza Zachodniego. Najwyższe 
wzniesienie na szlaku to 330 m n.p.m., znajduje się w Szczebrzeszyńskim Parku Krajobrazowym, natomiast najniżej położony teren (225 m n.p.m.) mieści się niedaleko Słodkowa Trzeciego. W większości trasa prowadzi po drogach asfaltowych, mało uczęszczanych przez samochody oraz obszarach leśnych i polnych, głównie między Dzielcami a Szczebrzeszynem (Turski i Wyszkowski 2006, s. 280). Obszar ten posiada lessowy krajobraz, gdzie można podziwiać głębokie rozcięcia erozyjne w postaci wąwozów i dolin, w niektórych miejscach wręcz powstają labirynty wąwozów. Niektóre wąwozy liczą nawet 20 metrów, a zbocza często porośnięte są grądami. Najciekawsze i największe wąwozy znajdują się w okolicy Szczebrzeszyna i zwane są popularne Piekiełkiem. Krajobraz Zachodniego Roztocza charakteryzuje się falistymi szachownicami pól uprawnych (Nasiadka 2005, s. 5-23).

Drugi etap szlaku biegnie od Zwierzyńca do Hrebennego, jego długość wynosi $86 \mathrm{~km}$. Szlak biegnie przez Zwierzyniec - Stawy Echo - Sochy - Szozdy Tereszpol - Górecko Stare - Józefów Biłgorajski - Hamernia - Nowiny - Majdan Sopocki - Oseredek - Susiec - Łosiniec - Mazily - Podleśna - Chyże Bełżec - Szalenik Kolonia - Lubycza Królewska - Teniatyska - Mosty Małe Hrebenne. Szlak ten prowadzi zarówno przez drogi asfaltowe, jak i piaszczyste (leśne i polne). Jadąc tym szlakiem można podziwiać wapienne wzgórza porośnięte lasami oraz rzeki tworzące kaskady wodospadów (popularnie zwane szumami). Wodospady te utworzyły się głównie na rzece Tanew oraz Sopot. Następnie szlak prowadzi przez Roztocze Wschodnie wzdłuż pagórków i wąwozów, płaskowyżów i garbów oraz kotlin i dolin (Pawłowski 2015, s.35-41). Występują tutaj ostańce, których wysokość sięga nawet do 390 m n.p.m. Teren ten pokryty jest mieszanymi lasami oraz buczyną karpacką. Roztocze to także pogranicze dwóch kultur: wschodniej i zachodniej. Na tym obszarze można podziwiać zarówno zabytkowe kościoły, cerkwie, jak i synagogi. Znajdują się tutaj pomniki historyczne, cmentarze $\mathrm{z}$ okresu powstania styczniowego, II wojny światowej oraz groby przypominające trudną sytuację Polaków w okresie powojennym (Turski i Wyszkowski 2006, s. 281).

Trzeci etap omawianego szlaku biegnie od Hrebennego do Lwowa. Szlak ten ma długość $80 \mathrm{~km}$ i prowadzi przez Hrebenne - Rawa Ruska - Potylicz Magierów - Żółkiew - Krechów - Iwano Frankowe - Brzuchowice - Lwów. Trasa ta niestety nie jest oznakowana $\mathrm{w}$ terenie, jednak głównie prowadzi przez drogi asfaltowe i utwardzone, rzadziej przez drogi piaszczyste i polne. Szlak ten biegnie przez ukraińskie Roztocze Wschodnie, ukazując całe jego piękno oraz 
urok okolicznych wsi i miasteczek. Na szlaku można podziwiać wychodnie skalne oraz kamieniołomy w Dubrowyczy oraz Potyliczu. Różnice wzniesień na trasie dochodzą nawet do $100 \mathrm{~m}$. Najwyższe wzniesienie to 400,3 m. n.p.m. w okolicy Dobroczynny (www.szlakirowerowe.lubelskie.pl).

\section{Wyniki badań}

Podczas badań przeprowadzono wywiady bezpośrednie z pracownikami urzędów gmin oraz obiektów noclegowych w celu ustalenia ilości miejsc noclegowych przyjaznych dla rowerzystów, tzn. takich gdzie turyści mogą zostawić bezpiecznie rower, przeprowadzić drobne naprawy, konserwację i umyć rower.

$\mathrm{Na}$ podstawie danych zamieszonych w tabeli 1 można zauważyć, że najwięcej obiektów noclegowych przyjaznych rowerzystom znajduje się w Zwierzyńcu (10), natomiast najwięcej miejsc noclegowych znajduje się w Suścu (aż 736). Dobrym miejscem na szukanie noclegu na omawianej trasie rowerowej jest także Górecko Stare, gdzie znajduje się 6 obiektów noclegowych z 76 miejscami, oraz Józefów (5 obiektów z 144 miejscami noclegowymi). W sumie na badanym szlaku znajdują się 54 obiekty z 1922 miejscami noclegowymi dostosowanymi do przyjęcia rowerzystów.

Tabela 1

Baza noclegowa przyjazna dla rowerzystów na Centralnym Szlaku Rowerowym Roztocza

\begin{tabular}{|l|c|r|r|r|}
\hline \multicolumn{1}{|c|}{ Miejscowość } & $\begin{array}{c}\text { Liczba } \\
\text { obiektów }\end{array}$ & $\begin{array}{c}\text { Odsetek } \\
\text { obiektów }\end{array}$ & $\begin{array}{c}\text { Liczba miejsc } \\
\text { noclegowych }\end{array}$ & $\begin{array}{c}\text { Odsetek miejsc } \\
\text { noclegowych }\end{array}$ \\
\hline Kraśnik & 4 & 7,41 & 104 & 5,22 \\
\hline Huta Józefów & 3 & 5,56 & 12 & 0,60 \\
\hline Batorz & 3 & 5,56 & 13 & 0,65 \\
\hline Chrzanów & 1 & 1,85 & 4 & 0,20 \\
\hline Radacznica & 1 & 1,85 & 50 & 2,51 \\
\hline Szczebrzeszyn & 2 & 3,70 & 64 & 3,21 \\
\hline Zwierzyniec & 10 & 18,52 & 392 & 19,68 \\
\hline Tereszpol & 3 & 5,56 & 15 & 0,75 \\
\hline Górecko Stare & 6 & 11,11 & 76 & 3,82 \\
\hline Józefów & 5 & 9,26 & 144 & 7,23 \\
\hline Hamernia & 1 & 1,85 & 4 & 0,20 \\
\hline Majdan Sopocki & 6 & 11,11 & 328 & 16,47 \\
\hline Susiec & 8 & 14,81 & 736 & 36,95 \\
\hline Lubycza Królewska & 1 & 1,85 & 50 & 2,51 \\
\hline Razem & 54,00 & 100,00 & 1992,00 & 100,00 \\
\hline
\end{tabular}

Źródło: opracowanie własne na podstawie badań sondażowych. 
Kolejne badania przeprowadzono na 175 rowerzystach. Wśród badanych osób 61,14\% stanowili Polacy, a 38,86\% - Ukraińcy. Na początku respondenci udzielali odpowiedzi na pytanie, jaki był główny cel uprawiania turystyki rowerowej na Centralnym Szlaku Rowerowym Roztocza, co przedstawiono na rys. 1

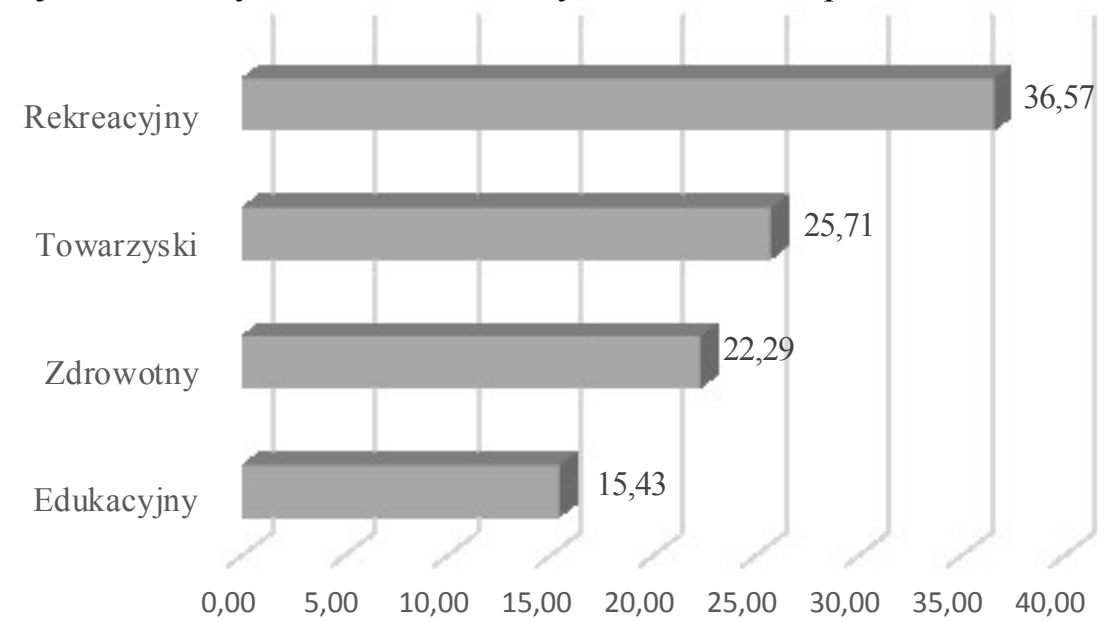

Rysunek1. Główne motywy uprawiania turystyki rowerowej na Centralnym Szlaku Rowerowym Roztocza przez respondentów (dane w \%, n = 175)

Źródło: opracowanie własne na podstawie badań

Głównym celem uprawiania turystyki rowerowej wśród respondentów był cel rekreacyjny, sprawdzenie własnych sił, wyrabianie zaradności i samodzielności oraz świadomej dyscypliny (36,57\% wskazań). Na drugim miejscu uplasował się cel towarzyski, czyli wspólne spędzanie czasu ze znajomymi i rodziną (25,71\% wskazań). Cel zdrowotny wskazało $22,29 \%$ badanych rowerzystów. Osoby te chciały stracić zbędne kilogramy oraz zdobyć kondycję sportową. Na cel edukacyjny, czyli poznanie przyrody, krajobrazu, kultury i historii regionu wskazało 15,43\% respondentów (rys. 1).

Dane na rys. 2 przedstawiają opinię respondentów na temat infrastruktury turystycznej na Centralnym Szlaku Rowerowym Roztocza. Rowerzyści oceniają najwyżej możliwość zwiedzania atrakcji na trasie, głównie przyrodniczych, historycznych oraz kulturowych ( $73,7 \%$ ocen dobrych i bardzo dobrych). Wysoko także zostały ocenione miejsca noclegowe, których jest duży wybór oraz możliwość dostosowania standardu do własnych potrzeb i możliwości finansowych $(72,0 \%$ ocen dobrych i bardzo dobrych). Natomiast najgorzej oceniono infrastrukturę higienic zno-sanitarną, której zdaniem respondentów na szlaku najczęściej brakuje lub wyma- 
ga remontów (28,0\% ocen złych i bardzo złych). Zastrzeżenia budzą taż usługi naprawcze, których na szlaku jest bardzo niewiele, lub jest brak informacji na temat świadczenia takich usług (21,1\% ocen złych i bardzo złych).

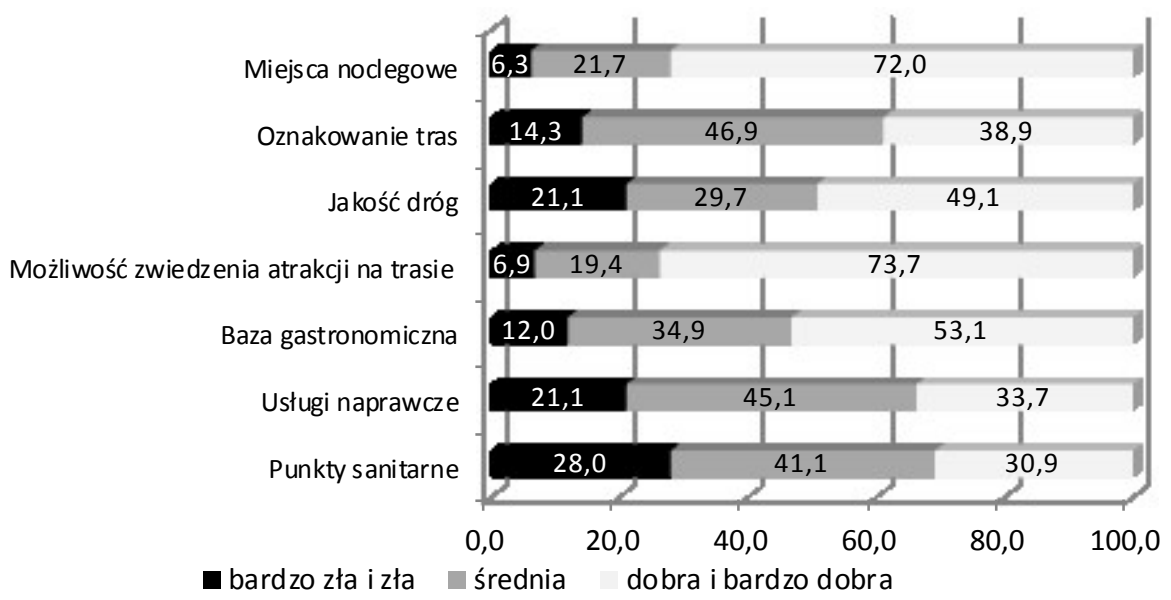

Rysunek 2. Ocena infrastruktury turystycznej i rowerowej na Centralnym Szlaku Rowerowym Roztocza w opinii respondentów (dane w \%, $\mathrm{n}=175$ )

Źródło: opracowanie własne na podstawie badań.

Na podstawie danych przedstawionych na rys. 3, można zauważyć że największą popularnością wśród rowerzystów cieszą się szczebrzeszyńskie lessowe wąwozy, tworzące labirynt ścieżek i szlaków turystycznych. Wąwozy znajdują się na terenie Szczebrzeszyńskiego Parku Krajobrazowego, a perełką tego miejsca zdaniem respondentów jest tzw. „szczebrzeszyńskie Piekiełko”, czyli głębokie wąwozy porośnięte drzewami, krzakami i innymi roślinami runa leśnego, gdzie panuje wieczny półmrok (60,00\% wskazań). Na drugim miejscu badane osoby wskazały wieś Szczebrzeszyn rozsławioną wierszem Jana Brzechwy „Chrząszcz”. Szczebrzeszyn słynie też ze swojej wielokulturowości, znajdują się tutaj dwa kościoły katolickie pw. św. Katarzyny oraz św. Mikołaja, najstarsza czynna w Polsce cerkiew Zaśnięcia Przenajświętszej Bogurodzicy oraz z XVII wieku synagoga (44,57\% wskazań). Ciekawym punktem na trasie jest także wieś Radecznica, zwana popularnie „lubelską Częstochową" ponieważ jest to miejsce lubelskich pielgrzymek do Sanktuarium św. Antoniego z Padwy (20,57\% wskazań). Kolejnym interesującym miejscem, na które wskazali badani rowerzyści jest Dolina Białej Łady, ze stromymi i wysokimi zboczami porośniętymi bukowym lasem, która tworzy w okolicy Goraja rekreacyjne stawy z kąpieliskiem (20,00\% wskazań) oraz Dolina Poru, z ciekawym roztoczań- 
skim krajobrazem rzeki wciętej w lessowe podłoże. Rowerzyści mogą tutaj spotkać liczne gatunki ptaków (16,00\% wskazań). Na kolejnym miejscu uplasowało się źródło Wyżnicy (13,14\% wskazań). Źródło to ma krystalicznie czystą wodę i stałą temperaturę $\left(8^{\circ} \mathrm{C}\right)$. Respondenci zwrócili także uwagę na wieś Otrocz, gdzie znajduje się XIX-wieczna cerkiew unicka, przemieniona w 1918 r. na kościół rzymskokatolicki. Szlak tutaj prowadzi przez doliny i wierzchowiny porosłe bukowym i grabowym lasem ( $8 \%$ wskazań).

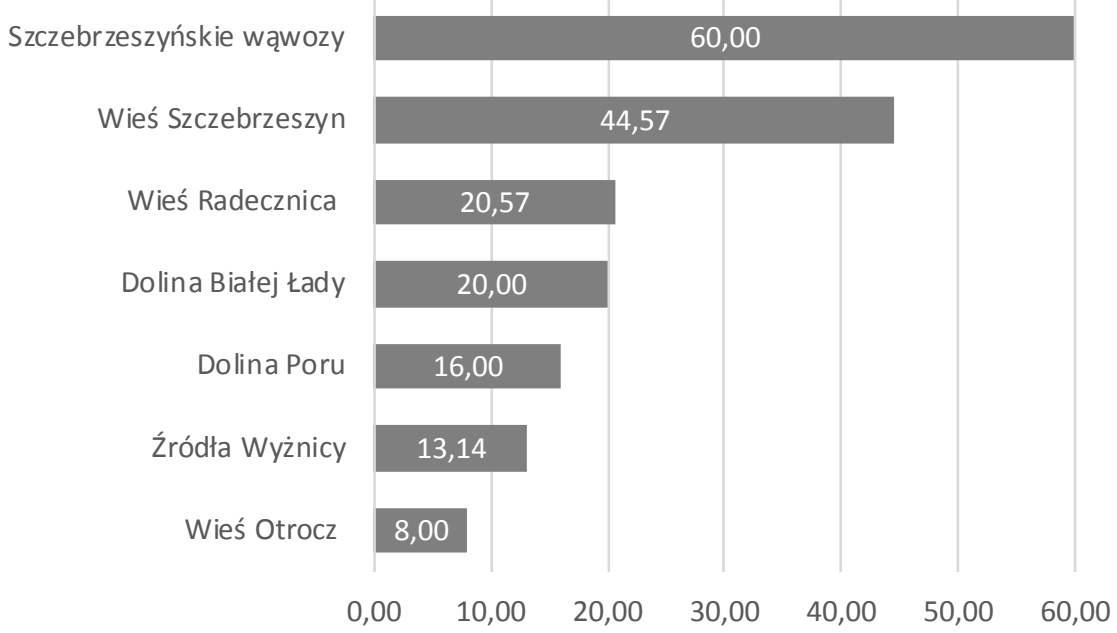

Rysunek 3. Ocena popularności atrakcji turystycznych na I etapie Centralnego Szlaku Rowerowego Roztocza w opinii respondentów (dane w \% - respondenci mogli wskazać więcej niż 1 odpowiedź)

Źródło: opracowanie własne na podstawie badań.

$\mathrm{Na}$ drugim etapie respondenci wskazali 7 ciekawych miejsc wartych zwiedzania, co przedstawiono na rys. 4. Na tym odcinku szlaku największym zainteresowaniem cieszy się Rezerwat „Nowiny” w Roztoczańskim Parku Narodowym. Rezerwat tworzą małe oczka wodne otoczone torfowiskiem, który chroni rzadkie gatunki roślin (96,57\% wskazań). Na drugim miejscu uplasowała się słynna miejscowość Zwierzyniec, z barokowym kościołem na wodzie p.w. św. Jana Nepomucena, dawną rezydencją plenipotenta (obecnie siedziba dyrekcji RPN, murowanym browarem z początku XIX w. (72,57\% wskazań). Kolejne miejsce zajmuje Rezerwat „Czartowe pole” z pięknymi wodospadami powstałymi na rzece Sopot (71,43\%). Na rezerwat „Jelinka”, który chroni skamieniałe drzewa z okresu trzeciorzędu zwróciło uwagę $63,43 \%$ badanych osób. Na kolejnym miejscu znalazła 
się wieś Górecko Kościelne, gdzie można zobaczyć XVIII-wieczny modrzewiowy kościół pw. św. Stanisława, oraz aleje pomnikowych dębów z wytyczoną drogą Męki Pańskiej wiodącą do kapliczki „na wodzie” (38,86\% wskazań). Kamieniołomy wapieni trzeciorzędowych "Babia Dolina" i "Tarnowolska Góra" w Józefowie doceniło 33,71\% rowerzystów. Na miejscowość Bełżec, gdzie był usytuowany hitlerowski obóz zagłady, a obecnie znajduje się mauzoleum oraz muzeum martyrologii wskazało $23,43 \%$ badanych osób.

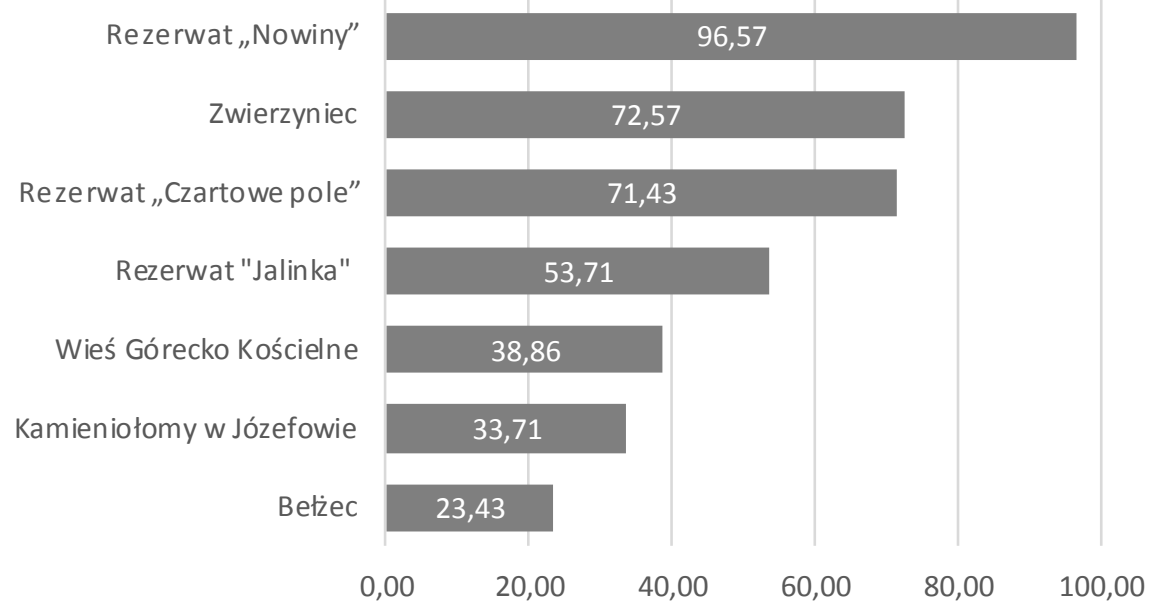

Rysunek 4. Ocena popularności atrakcji turystycznych na II etapie Centralnego Szlaku Rowerowego Roztocza w opinii respondentów (dane w \% - respondenci mogli wskazać więcej niż 1 odpowiedź)

Źródło: opracowanie własne na podstawie badań

$\mathrm{Na}$ trzecim etapie szlaku biegnącego głównie przez terytorium Ukrainy, respondenci wskazali na 6 obiektów wartych obejrzenia (rys. 5). Na tym odcinku najciekawszym miejscem jest ostatni odcinek szlaku, a mianowicie miasto Lwów z zabytkowym śródmieściem, które jest wpisane na listę Światowego Dziedzictwa Kultury UNESCO (59,43\% wskazań). Rezerwat Przyrody Roztocze chroniący wiele rzadkich gatunków roślin wpisanych do Czerwonej Księgi Ukrainy z muzeum przyrodniczym oraz ścieżką edukacyjno-ekologiczną uplasował się na drugim miejscu (50,86\% wskazań). Trzecie miejsce zajął XVIIIwieczny początkowo prawosławny, a potem unicki Monastyr w Krechowie, gdzie zachowały się bogate zbiory klasztornej biblioteki. W tym miejscu znajduje się także ścieżka, którą od XVI w. przebywali zakonnicy, wiodąca od bramy monastyru do wykutych w wapiennej skale ostańcowej pieczary $(32,57 \%$ wska- 
zań). Kolejne miejsce zajęła Góra Przemienienia Pańskiego z kapliczką, punktem widokowym oraz nieczynnym kamieniołomem w miejscowości Potylicz (30,86\% wskazań). Ścieżkę poznawczą "Lelechiwka" im. I. Franki - ukraińskiego poety o długości 4,5 km prowadzącą do "Czarnych Jezior" znajdującą się w Jaworowskim Narodowym Parku Przyrodniczym doceniło 26,86\% badanych osób. Na źródła i stawy na strumieniu Tylica, dopływie Raty w miejscowości Potylicz zwróciło uwagę 13,14\% respondentów.

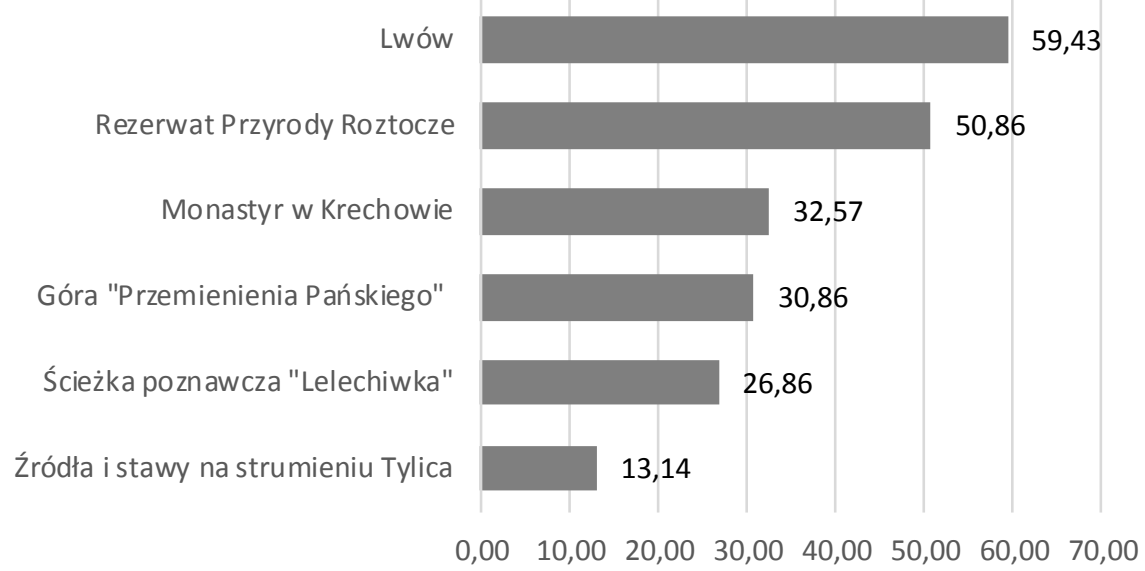

Rysunek 5. Ocena popularności atrakcji turystycznych na III etapie Centralnego Szlaku Rowerowego Roztocza w opinii respondentów (dane w \% - respondenci mogli wskazać więcej niż 1 odpowiedź)

Źródło: opracowanie własne na podstawie badań.

\section{Podsumowanie}

Centralny Szlak Rowerowy Roztocza jest jednym z ciekawszych szlaków rowerowych na Lubelszczyźnie. Jest to transgraniczny szlak, który zaczyna się w Kraśniku, a kończy we Lwowie, jego całkowita dhugość wynosi 267 km. Badani rowerzyści najwyżej oceniają na szlaku atrakcje, zarówno przyrodnicze, kulturowe, jak i historyczne (73,7\% ocen bardzo dobrych i dobrych) oraz dużą liczbę miejsc noclegowych dostosowanych do potrzeb turystów (72,0\% ocen bardzo dobrych i dobrych). Na pewno należałoby zadbać o więcej publicznych sanitariatów oraz remonty już istniejących oraz więcej miejsc naprawy i konserwacji rowerów, poprawić oznakowanie trasy szlaków, zwłaszcza w części ukraińskiej, jak również na niektórych odcinkach poprawić jakość dróg, zwiększając jednocześnie bezpieczeństwo rowerzystów. 
Największymi perełkami turystycznymi na omawianej trasie według respondentów jest: Rezerwat Przyrody „Nowiny” (95,57\%); miejscowość Zwierzyniec (72,57\%); Rezerwat Przyrody „Czartowe pole” (71,43\%); Szczebrzeszyńskie Wąwozy $(60,00 \%)$ oraz miasto Lwów $(59,43 \%)$.

\section{Bibliografia}

Buczyński A., Turystyka rowerowa w Polsce. MSiT, Warszawa 2013.

Hajduk S., Szlakiturystyczne jako elementintegracjiregionówtransgranicznych, Człowiek i Środowisko, nr 31, 2007, s. 87.

Kopta T., Standardy dla trasy rowerowej realizowanej w ramach Programu Operacyjnego Rozwój Polski Wschodniej, PARP, Warszawa 2010.

Krawczyńska M., Definicja szlakówturystycznych. Regionalny Ośrodek Programowy PTTK. Gdańsk 2012.

Nasiadka M., Roztocze Zachodnie. Wydawnictwo Naukowe Turystyczne i Edukacyjne. Mielec 2005.

Pawłowski A., Roztocze. REFASZ, Piastów 2015.

Sawicki B., Turystyka transgraniczna w powiecie żarskim. w: A. Przybyła, W. Wytrążek, Prawne i gospodarcze aspekty działalności w turystyce, Wydawnictwo W schód Agencja Usługowa Stanisław Filas. Lublin 2010, s. 237-246.

Stasiak A., Szlaki turystyczne - zagospodarowanie, atrakcja czy produktturystyczny, Turystyka i Hotelarstwo, nr 10, 2006, s. 45-53.

Styperek J., Linearne systemy penetracji rekreacyjnej. WNB. Poznań 2002.

Turski S., Wyszkowski M., Lubelszczyzna Przewodnik. Lublin:, Wydawnictwo Bespol.

Centralny Szlak Rowerowy Roztocza. 2006, www.szlakirowerowe.lubelskie.pl (dostęp 15.07.2016 r.).

Zarząd Główny PTTK, Znakowanie szlaków turystycznych, Wydawnictwo PTTK Kraj. Warszawa 2007.

\section{The evaluation of the quality facility of the Central Road Bike of Roztocze}

\section{Summary}

The Central Road Bike of Roztocze are one of the most interesting cycling routes in the Lublin region. It is a cross-border route, which begins in Kraśnik and ends in Lvov, its total length is $267 \mathrm{~km}$. According to the cyclists on the route they are very interesting attractions, both natural, cultural, and historical ( $73.7 \%$ rating very good and good) and a large number of beds to meet the needs of tourists ( $72.0 \%$ of very good and good). Certainly we had to take care on the trail of more public toilets and the renovation of existing ones, and more repair and maintenance of bicycles. Improve marking the route routes, especially in the part of Ukrainian, as well as some sections to improve the quality of roads, while ensuring the safety of cyclists. According to respondents the biggest tourist pearls on the route is: Nature Reserve "Nowiny" (95.57\%); town Zwierzyniec (72.57\%); Nature Reserve "Czartowe pole" $(71.43 \%)$; ravine in Szczebrzeszyn $(60.00 \%)$ and city of Lvov $(59.43 \%)$. 